\title{
The Effect of Eye-Hand Coordination Training on Accuracy of Service in Volleyball Players
}

\author{
H. Ngadiyana \\ Department of Sport Education and Health \\ Lambung Mangkurat University \\ Banjarmasin, Indonesia \\ hajingadiyana@yahoo.com
}

\begin{abstract}
This study aims to determine the effect of eyehand coordination exercises on the accuracy of top service for volleyball players. The research method used is the preexperiment design method. The samples in this study were 24 volleyball players in SMA Negeri 1 Angsana, Tanah Bumbu Indonesia, which were divided into two groups: the treatment group was twelve people and the control group was 12 people. The samples were selected using saturated sampling techniques. The instrument used to measure the accuracy of service for volleyball with a service test for volleyball (Nurhasan, 2007: 225). Data analysis techniques using the Hypothesis Test (average comparison analysis) paired-samples T-test (C. Trihendradi, 2013: 119). The results showed that the pretest data on the service accuracy of the volleyball players at SMAN 1 Angsana, Tanah Bumbu, obtained an average of 11.83 with a standard deviation $=\mathbf{5 . 5 4 0}$. In the post-test data on service accuracy, the average is 21.17 with a standard deviation $=7.445$. While obtained $t$-count $=6.642>t$-table $(11$; $0.025)=2.201$, with Sig. $(2$-tailed $)=0,000$; it turns out that Sig. (2-tailed) $<0.05$ thus the $t$-count is significant. The conclusion is that there is an influence of eye-hand coordination exercises on the accuracy of top service. It implies that to improve the top serviceability of volleyball players can be conducted by implementing eye-hand coordination exercise.
\end{abstract}

Keywords: training, coordination, eyes, hands, accuracy, upper service, volleyball

\section{INTRODUCTION}

Volleyball is a game that is played in a team with 6 players in each team. There are 6 reserve players for each team. The field is limited by the net with a height of 2.43 meters for men and for girls 2.24 meters. The length of the field is 18 meters and the width is 9 meters. in order to be good and skilled at playing volleyball, the player must master some of the techniques of the game. The basic technique of playing volleyball can be mastered with some intensive training by applying training programs and methods. In carrying out the volleyball training process must be based on the development and physical growth of the child or the player itself.

Volleyball in South Kalimantan is very well-organized. Volleyball club organization is shown from the number of volleyball clubs owned by each City / Regency. Volleyball clubs not only in public clubs, but even every level of elementary, middle and high school also have clubs that are fostered through extracurricular activities.
The volleyball extracurricular implementation at SMAN 1 Angsana runs every year, but the achievements have not yet reached optimal performance. This is because the training program that was made was not yet on target. While this exercise frequency is only once a week, on the other hand the intensity of training, service, smash and block are very low. Then other causes seen from physical exercise are not following physical exercise guidelines, this also causes some athletes to not achieve good physical condition, including: (1). lack of strength, (2) lack of endurance, (3) lack of speed, (4) lack of agility, (5) lack of flexibility.

The service punch is the initial blow and can be the first strike when the service ball is hit hard and directed. Servicing must be done well, directed and perfect by all players. A service error can result in the opponent earning points. Thus the importance of the service position in the volleyball game, the basic technique of service must be paired-samples. Service training must get enough portions to be able to achieve maximum results.

Many factors become a lack of strength causes obstacles in the mastery of the ability to service poorly, often touching the net, and often coming out (out). It is hoped that the volleyball player of SMAN 1 Angsana has the strength so that the ability to service can be done well because the top service requires arm muscle strength and good eye-hand coordination.

Many factors that cause the top service does not produce points, why, among others, from physical conditions that is not optimal arm muscle power. One of the physical requirements for volleyball players has excellent physical conditions to be developed into a good player: having speed, coordination, flexibility, power, stamina, agility, and strength [1]. Service that results are good and maximum, also requires good eye-hand coordination.

Eye-hand coordination is important in volleyball games. When performing service punches and passing requires the arm, to do top service and requires good eye-hand coordination, when the arm muscle strength is lacking, so that the service is not optimal and can touch the net, when eye-hand coordination is less than in directing the ball less right on target. The same problem happened to volleyball player SMAN 1 Angsana.

The upper service technique is a fusion of cooperative movements between the arm muscles. There are 3 muscles 
and then in the division of groups by the ordinal pairing method, so that both groups depart from the same ability. strength of the arm muscles that are strong enough and directed, especially the deltoid muscles so that the base of the arm which is also supported by pectoralis major and lattisimus dorsi; (2) when hitting the ball. At this stage it is an important phase in performing service techniques, strength rests on the muscles of the shoulder, chest, triceps and wrist; (3) follow-through, an advanced stage, this shows that the upper limb group functions optimally. Based on this background it was emphasized that the service of the main movable muscle components is the chest muscles, arm muscles, back muscles and the constituent muscles of the wrist and fingers. These muscle components can play a very good role in influencing success in servicing the top.

Success in a serving depends on the speed of the ball, the road and the ball's spin and accuracy in directing the ball to an empty spot, to the backline players who make a move [2]. In performing a series of service movements one of the body's organs that plays a lot is the arm. The arm serves to hit the ball. To make perfect upper service movements requires good arm muscle strength. Arm muscle strength as the thrust of continued arm movements results in a stronger ball strike. The strength of the arm muscles performed during the service movements of the upper hand greatly affects the speed and severity of the blow. From this it shows that the arm muscle strength is a huge role in creating a good service, strong and precise. These muscles can work well if given training or treatment. Exercises for arm muscles by throwing the ball on the net with both hands to stimulate the muscles to be stronger and more trained and train eye-hand coordination so that they are able to work well when doing top service.

There are six types of service in volleyball, namely: (1) side-hand service, (2) underhand service, (3) over-head service (overhead) service), (4) jump service, (5) topspin service and (6) floating service [3].

The top service technique has the advantage of being a fastball and close to the net or net so that it makes it difficult for your opponent. When performing service techniques requires three conditions, namely: (1) strength in the arm muscles, (2) speed of the results of the blow and (3) accuracy of the target. Arm muscle strength is needed when serving up to hit the ball to get to the opponent's area quickly, while eye-hand coordination is needed to obtain accuracy in serving.

As a way out to solve the problem, research is needed to find out how the influence of eye-hand coordination exercises on the accuracy of service for men's volleyball players in SMA Negeri 1 Angsana, Tanah Bumbu Regency.

\section{Methodology}

The method used in this research is pre-experiment design [4]. It is said pre-experiment design, because the design of this study has not been actual research, or the influence of external variables on independent variables, researchers cannot fully limit activities to the sample, because human samples have their respective activities, their students have their respective activities both at school and outside of school, so researchers cannot limit the full range of activities carried out in daily samples. This variable uses a control variable, by calculating the results of the initial test
The design in this study used the One-Group Pretest-Posttest Design, which means that before the treatment was given the interpretation, and after the treatment was given the posttest. Thus the results of the treatment are known to be more accurate, because they can compare with the conditions before being given treatment

\section{RESULTS AND DISCUSSION}

This study proves that eye-hand coordination training, throwing the ball with two hands towards the net can significantly improve $(\mathrm{p}<0.05)$ accuracy of volleyball service for male volleyball players in SMA Negeri 1 Angsana. This is evidenced by t-count $=6,642>\mathrm{t}$-table (11; $0,025)=2,201$, or with Sig. (2-tailed) $=0,000$; it turns out that Sig. (2-tailed) $<\alpha=0.05$ thus the t-count is significant and the hypothesis proposed in this study is proven true. The results above prove that there is a positive and significant influence on eye-hand coordination training, throwing the ball with two hands towards the net towards the accuracy of the service on volleyball for male volleyball players of SMA Negeri 1 Angsana.

The exercise program is carried out with the following stages: warm-up, core exercises of eye-hand coordination exercises and end with cooling. Exercise or treatment of throwing the ball, for 6 weeks or 18 meetings with a frequency of 3 times a week held at SMA Negeri 1 Angsana for participants who take volleyball extracurricular activities. In eye-hand coordination training, that is by throwing the ball with two hands, from behind the service line towards the net before carrying out the exercise the maximum test is throwing the ball with two hands, because the ability of each sample is different, from the maximum test used as a measure of the ability of the sample to be multiplied by the presentation of the intensity of the exercise to be applied. In this study of the implementation of eye-hand coordination exercises with throwing a ball with two hands has an intensity of $80-90 \%$. So the researchers tried to vary the intensity from $80 \%$ to $90 \%$ intensity. In the first and second weeks applying the intensity of $80 \%$, then in the third and fourth weeks applying the intensity of $85 \%$, and in the fifth week the researcher tried to apply the intensity of $90 \%$, while at the 17th and 18th meeting again the intensity of the exercise was $85 \%$ in order to do the final test sample does not experience fatigue, meaning that the muscles that have been trained have recovered, so that the final test will be maximized.

Eye-hand coordination exercises namely by throwing the ball using both hands are arranged correctly based on the principles of training, by providing increased training load during 18 meetings, the movement of jumping the ball with both hands trains the strength of the arm muscles which gives an influence on the accuracy of the top service, because in this exercise besides using the strength of both hands also learn to direct the ball, then the exercise can affect the accuracy of service for volleyball players. The relationship of coordination or the hand has a relationship to the ability to service [5], besides it that there is an influence of eye coordination exercises on the ability of volleyball service [6]. This shows that there is an influence of eye-hand coordination training on the volleyball serviceability of the players. 


\section{REFERENCES}

The steps in drawing the conclusions of this research are based on data analysis, hypothesis testing and the discussion that has been carried out in the previous chapter. The results of this study can be concluded that there is an influence of eye-hand coordination exercises on the accuracy of service for volleyball in male volleyball players.

\section{ACKNOWLEDGMENT}

We would like to be grateful to the Dean of Teacher Training and Education Faculty, Lambung Mangkurat University, who has supported us in the form of funding. Therefore we could join this International seminar.
[1] Yunus, M, 1992. Olahraga Pilihan Bola Voli. Jakarta: Departemen Pendidikan dan Kebudayaan Direktorat Jenderal Pendidikan Tinggi Proyek pembinaan Tenaga Kependidikan.

[2] Muhajir, 2007. Pendidikan Jasmani, Olahraga dan Kesehatan Untuk SMA Kelas XI. Bandung: Erlangga.

[3] Ahmadi, Nuril. 2007 . Panduan Olahraga Bola Voli. Solo: Pustaka Utama

[4] Sugiyono, 2014. Metode Penelitian Kombinasi (Mixed Methods). Bandung: Alfabeta.

[5] Bowo, Y. R. H. (2016). Hubungan Antara Kekuatan Genggaman, Koordinasi Mata-Tangan Dan Percaya Diri Dengan Ketepatan Service. Jurnal Dewantara, 2(02), 179-196.

[6] Sari, Y. B. C., \& Guntur, G. (2017). Pengaruh metode latihan dan koordinasi mata-tangan terhadap hasil keterampilan servis atas bola voli. Jurnal Keolahragaan, 5(1), 100-110. 